\title{
Structure and Dynamics of Phytoplankton Community in the Botafogo Reservoir-Pernambuco-Brazil
}

\author{
Giulliari Alan da Silva Tavares de Lira ${ }^{1}$, Maria do Carmo Bittencourt-Oliveira ${ }^{2}$ and \\ Ariadne do Nascimento Moura ${ }^{1^{*}}$ \\ ${ }^{I}$ Departamento de Biologia; Universidade Federal Rural de Pernambuco; Rua Dom Manoel de Medeiros s/n; \\ 52175-030; Recife - PE - Brasil. ${ }^{2}$ Departamento de Ciências Biológicas; Escola Superior de Agricultura Luiz de \\ Queiroz; Universidade de São Paulo; Piracicaba - SP - Brasil
}

\begin{abstract}
The aim of the present study was to investigate the structure and dynamics of the phytoplankton in the Botafogo reservoir-PE-Brazil. Phytoplankton assemblages were identified from current literature and density was estimated using an inverted microscope. Concurrently to the sampling of biotic variables, measurements of abiotic parameters, such as water temperature, dissolved oxygen and $\mathrm{pH}$, were determined using field probes and transparency was determined with a Secchi disk. Total phosphorus and total nitrogen concentrations were determined in laboratory. A total of 24 taxa were identified. Chlorophyta presented the greatest number of species. Species diversity in the reservoir was low throughout the study period. Principal component analysis revealed that Trachelomonas volvocina, Chlorella vulgaris, Euglena sp. and Peridinium gatunense were directly correlated with oxygen, turbidity and total nitrogen; Planktosphaeria gelatinosa, P. gatunense and Euglena sp. were directed correlated with total nitrogen; rainfall explained the occurrence of Monoraphidium arcuatum and Chlorella vulgaris.
\end{abstract}

Key words: Structure, Tropical reservoir, Phytoplankton, Brazil

\section{INTRODUCTION}

Reservoirs respond to physical (influx radiation, evaporation, wind, drainage, etc.), chemical (precipitation, sedimentation, etc.) and biological influences from the natural environment. They are also very sensitive to human activities due to their function as collectors and processors of material from anthropogenic activities such as agriculture, animal pasturing, recycling, etc. (Straskraba and Tundisi, 2000). Tropical reservoirs are special aquatic ecosystems in which physical, chemical and biological characteristics are strongly controlled by the input of water from rivers and periodic dewatering (Thornton et al., 1990). The study of the phytoplankton community in reservoirs has attracted much attention from researchers as an indicator of changes in the trophic-dynamic conditions of these ecosystems (De Bernardi, 1984). According to Tundisi (1999), the study of dynamic systems such as reservoirs has contributed greatly to the understanding of basic questions in the field of ecology, such as succession in communities, colonization patterns and pulse effects. Numerous

\footnotetext{
* Author for correspondence: ariadne@db.ufrpe.br
} 
studies have shown that the analysis of phytoplankton is fundamental to the biological monitoring of these systems, furnishing basic information regarding the establishment of norms for water quality control (Sant'Anna et al., 1997).

Studies on reservoirs have generally dealt with the structural and behavioral composition of the phytoplankton community, with focus on taxonomic surveys and ecological studies. In Brazil, most studies on reservoirs have been carried out in the South and Southeast regions (Calijuri and Dos Santos, 2001; Figueredo and Giani, 2001; Calijuri et al., 2002; Marinho and Huszar, 2002; Henry et al., 2006) and are mainly about seasonal and circadian variations, with only a few addressing short-term periods. Very few work has been developed on reservoirs in the Northeastern region; Chellapa et al. (1990; 1998) and Costa et al. (2006) conducted studies in the state of Rio Grande do Norte; Bouvy et al. (2000), Bouvy et al. (2001), Falcão et al. (2002) and Bouvy et al. (2003) conducted studies in the state of Pernambuco.

Considering the importance of phytoplankton studies in reservoir ecosystems, the aim of the present study was to analyze the phytoplankton community of the Botafogo reservoir (Pernambuco, Brazil), characterizing the structure and biota dynamics as well as interactions with abiotic factors.

\section{MATERIAL AND METHODS}

The Botafogo Reservoir is part of the water supply system of the state of Pernambuco, Brazil and is located in the district of Igarassu $\left(07^{\circ} 53^{\prime} 02^{\prime \prime} \mathrm{S}\right.$ $35^{\circ} 03^{\prime} 32^{\prime \prime} \mathrm{W}$ (Fig.1). It is important for irrigation and fishing activities. The reservoir has high accumulation capacity $\left(28.8 \times 10^{6} \mathrm{~m}^{3}\right)$ and is located in a humid climate region with total annual precipitation greater than $1000 \mathrm{~mm}$. There are two well-defined seasons in this region: the rainy season (March to August) and the dry season (September to February).

Two sampling stations were established in the pelagic zone of the reservoir: Station 1 ( $7^{\circ} 50^{\prime} 23^{\prime \prime} \mathrm{S}$ and $\left.35^{\circ} 01^{\prime} 50^{\prime \prime} \mathrm{W}\right)$ and Station 2

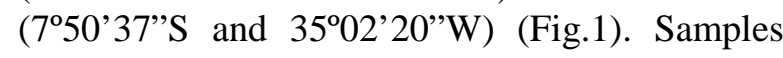
for nutrient and biological analysis were collected from the subsurface using a recipient with a large overture. Further samples were collected from the bottom with a Van Dorn bottle. Samplings were carried out for seven consecutive days during both the rainy season (July 2003) and dry season (January 2004), in which six days were used as replicas of the first. Water transparency was determined with a $25-\mathrm{cm}$ diameter Secchi disk. A field probe was used to determine water temperature $\left(\mathrm{T}^{\circ} \mathrm{C}\right)$, total dissolved solids (TDS $\left.\mathrm{mg} . \mathrm{L}^{-1}\right)$, electrical conductivity $\left(\mu \mathrm{S} . \mathrm{cm}^{-1}\right)$, dissolved oxygen (mg. $\left.\mathrm{L}^{-1}\right)$, turbidity (NTU) and pH. Total nitrogen ( $\mu$ g.NT. $\left.L^{-1}\right)$ and total phosphorus $\left(\mu \mathrm{g} . \mathrm{PT} . \mathrm{L}^{-1}\right)$ levels were determined using the method described by Valderrama (1981). Samples for taxonomic analyses were preserved in formaldehyde $4 \%$ and identification performed using an optical microscope (Zeiss/Axioskop) down to the species level or to the highest possible taxonomic resolution using the relevant literature (Round et al., 1990; Sant'Anna, 1984; Komarék and Foot, 1983; Komárek and Anagnostidis, 1999; Komárek and Anagnostidis, 2005). Aliquots of $100 \mathrm{~mL}$ of water were collected daily from the reservoir and preserved in acetic Lugol's solution for the determination of cellular density $\left(\right.$ Cel. $\left.\mathrm{L}^{-1}\right)$ according to the Utermöhl method (Utermöhl, 1958).

The Diversity Index was calculated using the Shannon and Wiener Index (Shannon and Weaver, 1948), considering:

$$
\mathrm{H}^{\prime}=-\Sigma \text { pi } . \log _{2} \text { pi, where pi }=\mathbf{N i} / \mathbf{N}
$$

$\mathbf{N i}=$ number of individuals of each species and $\mathbf{N}$ $=$ total number of individuals. The results were expressed in bits.cel ${ }^{-1}$.

Equitability $(J)$ was calculated with Shannon and and Wiener index, Shannon and Weaver, 1948. Variance (ANOVA) was calculated for each sampling station, depth and season, with significance set at 5\% and using BioEstat 3.0 (Ayres et al., 2003) with significance set at 5\% and $1 \%$.

All environmental variables and the abundant species in either sampling unit for the two periods analyzed were considered in the principal component analysis (PCA), using the NTSYS program, version 2.1 for Windows, 2000. 


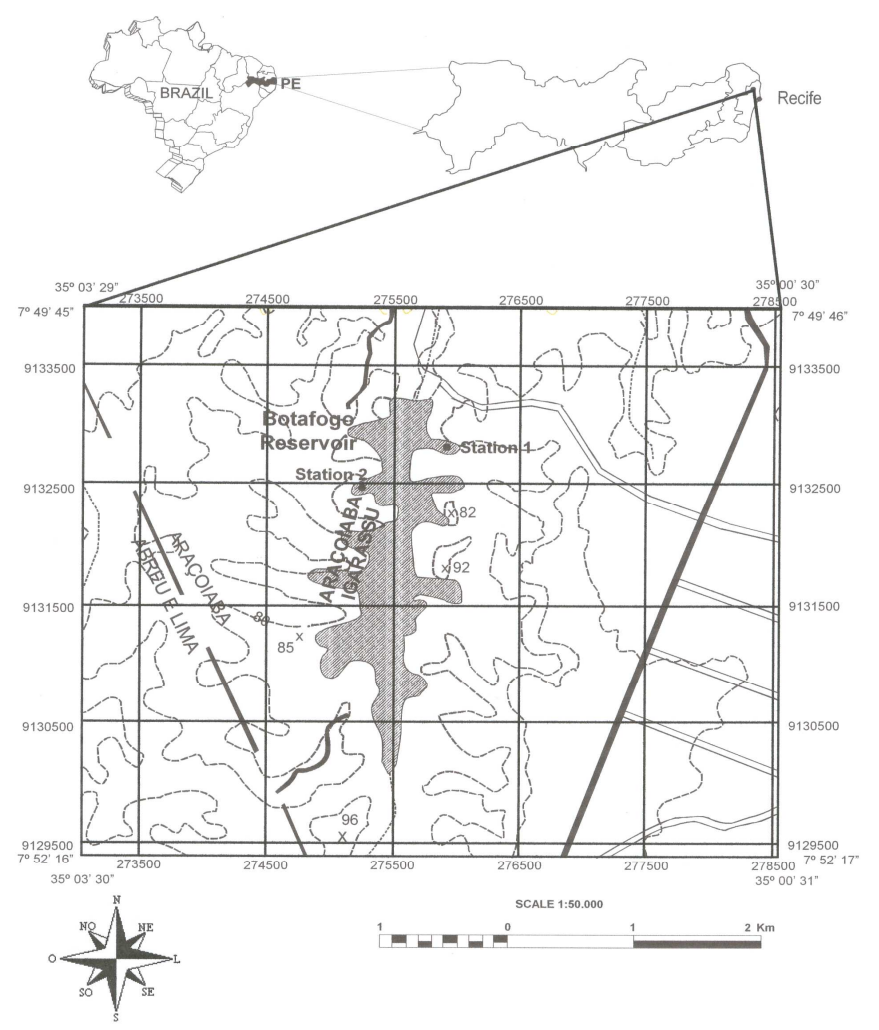

Figure 1 - Map of the Botafogo Reservoir, Pernambuco-Brazil, showing sampling stations. Source: Technology Institute of Pernambuco.

\section{RESULTS}

\section{Limnological variables}

Table 1 displays the mean values of the physicochemical variables at both sampling stations during dry and wet seasons. Significant differences were observed between the two seasons for all abiotic variables $(\mathrm{p}<0.01)$, except total phosphorus (p>0.05) (Table 2).
Dissolved oxygen, total nitrogen and turbidity were lower during the dry season (Table 1). Water transparency, water temperature, $\mathrm{pH}$, electric conductivity and total dissolved solids were higher in the dry season, but there were no clear pattern of variation between vertical or horizontal sampling stations. Temperature exhibited differences between depths $(\mathrm{p}<0.05)$ at both sampling stations and in both climatic seasons (Tables 1 and 2).

Table 1 - Mean values of the physical and chemical variables of the Botafogo Reservoir, Pernambuco State, Brazil at sampling stations $S_{1}$ e $S_{2}$ at the subsurface and bottom during the dry and rainy seasons. (S1S): Station 1 Subsurface; (S1B): Station 1 Bottom; (S2S): Station 2 Subsurface; (S2B): Station 2 Bottom.

\begin{tabular}{|c|c|c|c|c|c|c|c|c|}
\hline \multirow{2}{*}{ Variables (Mean values) } & \multicolumn{4}{|c|}{ Rainy season } & \multicolumn{4}{|c|}{ Dry season } \\
\hline & S1S & S1B & S2S & S2B & S1S & S1B & S2S & S2B \\
\hline Secchi disk $(\mathrm{m})^{\boldsymbol{\Lambda}}$ & 0.84 & - & 0.84 & - & 1.30 & - & 1.30 & - \\
\hline Oxygen $\left(\mathrm{mg} \cdot \mathrm{L}^{-1}\right)^{\boldsymbol{\Lambda}}$ & 3.51 & 3.19 & 3.35 & 3.20 & 0.85 & 0.82 & 1.20 & 1.03 \\
\hline perature $\left({ }^{\circ} \mathrm{C}\right)$ & $27.30 *$ & 26.80 & $27.00 *$ & 26.90 & $30.00 * *$ & 29.30 & $30.40 * *$ & 29.60 \\
\hline $\mathrm{pH}^{\mathbf{\Lambda}}$ & 6.36 & 6.20 & 6.41 & 6.29 & 6.60 & 6.50 & $6.69 * *$ & 6.37 \\
\hline Total dissolved solids $\left(\mathrm{mg} \cdot \mathrm{L}^{-1}\right) \boldsymbol{\Lambda}$ & 54.10 & 55.10 & 55.10 & 55.40 & 58.00 & 58.20 & 58.70 & 58.70 \\
\hline ctivity $\left(\mu \mathrm{S} . \mathrm{cm}^{-1}\right) \boldsymbol{\Delta}$ & 54.40 & 55.30 & 55.10 & 55.60 & 58.30 & 58.40 & 58.90 & 58.90 \\
\hline Turbity (NTU) & 18.10 & 18.40 & 18.20 & 20.60 & 4.70 & 4.90 & 4.70 & 4.40 \\
\hline Total nitrogen $\left(\mu \mathrm{g} . \mathrm{L}^{-1}\right)^{\boldsymbol{\Lambda}}$ & 3.70 & 2.71 & 1.70 & 2.73 & 0.36 & - & - & - \\
\hline Total phosphorus $\left(\mu \mathrm{g} . \mathrm{L}^{-1}\right)$ & $111.40 *$ & 117.10 & 112.80 & 114.20 & 110.00 & 117.10 & $110.00 * *$ & 117.10 \\
\hline
\end{tabular}

${ }^{\mathbf{A}}$ Difference between seasonal periods $(\mathrm{p}<0.01)$; Difference between depths: ${ }^{*} \mathrm{p}<0.05,{ }^{* *} \mathrm{p}<0.01$ 
Table 2 - Results from ANOVA for the assessment of temporal and spatial differences of abiotic variables in the Botafogo Reservoir, Pernambuco State, Brazil.

\begin{tabular}{|c|c|c|c|c|c|c|c|c|c|c|c|c|c|c|}
\hline \multirow{4}{*}{ Variables } & \multicolumn{8}{|c|}{ Depths } & \multirow{2}{*}{\multicolumn{4}{|c|}{ Season }} & \multirow{2}{*}{\multicolumn{2}{|c|}{ Periods }} \\
\hline & \multicolumn{4}{|c|}{ Rainy } & \multicolumn{4}{|c|}{ Dry } & & & & & & \\
\hline & \multicolumn{2}{|c|}{ Station 1} & \multicolumn{2}{|c|}{ Station 2} & \multicolumn{2}{|c|}{ Station 1} & \multicolumn{2}{|c|}{ Station 2} & \multicolumn{2}{|c|}{ Rainy } & \multicolumn{2}{|c|}{ Dry } & \multirow[b]{2}{*}{$\mathbf{F}$} & \multirow[b]{2}{*}{$\mathbf{p}$} \\
\hline & $\mathbf{F}$ & $\mathbf{p}$ & $\mathbf{F}$ & $\mathbf{p}$ & $\mathbf{F}$ & $\mathbf{p}$ & $\mathbf{F}$ & $\mathbf{p}$ & $\mathbf{F}$ & $\mathbf{p}$ & $\mathbf{F}$ & $\mathbf{P}$ & & \\
\hline Dissolved oxygen & 1.99 & 0.184 & 0.65 & 0.436 & 0.00 & 0.947 & 0.14 & 0.717 & 0.27 & 0.611 & 0.63 & 0.436 & 148.01 & 0.000 \\
\hline Water temperature & 8.24 & 0.014 & 7.66 & 0.017 & 36.48 & 0.000 & 50.94 & 0.000 & 0.15 & 0.703 & 5.53 & 0.027 & 542.93 & 0.000 \\
\hline $\mathrm{pH}$ & 2.20 & 0.164 & 3.00 & 0.109 & 1.29 & 0.278 & 10.11 & 0.008 & 1.04 & 0.318 & 0.14 & 0.713 & 17.58 & 0.000 \\
\hline $\begin{array}{l}\text { Total dissolved } \\
\text { solids }\end{array}$ & 1.18 & 0.299 & 0.18 & 0.675 & 0.22 & 0.646 & 0.00 & 1.000 & 1.30 & 0.265 & 2.42 & 0.132 & 103.31 & 0.000 \\
\hline Eletric condutivity & 1.18 & 0.299 & 0.43 & 0.522 & 0.00 & 0.962 & 0.00 & 0.972 & 0.77 & 0.389 & 2.69 & 0.113 & 118.99 & 0.000 \\
\hline Turbity & 0.09 & 0.773 & 1.11 & 0.313 & 0.93 & 0.355 & 0.81 & 0.385 & 0.91 & 0.349 & 1.40 & 0.247 & 525.22 & 0.000 \\
\hline Secchi disk & - & - & - & - & - & - & - & - & 0.12 & 0.739 & 0.01 & 0.912 & 127.76 & 0.000 \\
\hline Total nitrogen & 1.68 & 0.219 & 3.47 & 0.087 & 1.74 & 0.212 & $*$ & $*$ & 4.04 & 0.055 & 1.65 & 0.211 & 94.70 & 0.000 \\
\hline Total phosphorus & 6.00 & 0.031 & 0.27 & 0.611 & 2.88 & 0.115 & 15.00 & 0.002 & 0.14 & 0.712 & 0.00 & 1.000 & 0.05 & 0.823 \\
\hline
\end{tabular}

Legends: * : Data missing, - : Analysis not applied.

\section{Species Composition}

Twenty four taxa were identified in the Botafogo Reservoir from the following divisions: Chlorophyta (Chlorella vulgaris Beijerinck, Eudorina elegans Ehrenberg, Golenkinia radiata Chodat, Kirchneriella lunaris (Kirchner) Möbius, Monoraphidium arcuatum (Korshikov) Bourelly, Planktosphaeria gelatinosa G. M. Smith, Sphaerocystis planctonica (Korshikov) Bourelly, Staurastrum leptocladum Nordstedt, Staurastrum paradoxum Meyen, Tetraedrum victorae Wolosynka), Cyanophyta (Aphanocapsa sp., Chroococcus limneticus Lemmermann, Chroococcus minutus Kützing, Chroococcus turgidus Kützing, Geitlerinema amphibium (Agardh ex Gomont) Anagnostidis, Merismopedia punctata Meyen, Microcystis aeruginosa (Kützing) Kützing, Microcystis incerta (Lemmermann) Emend. Starmach and Oscillatoria sp.), Euglenophyta (Euglena sp. and Trachelomonas volvocina (Ehrenberg), Bacillariophyta (Aulacoseira granulata (Ehrenberg) Simonsen, Dinophyta (Peridinium gatunense Nygaard) and Chrysophyta (Mallomonas sp.).

\section{Density}

Total density varied from $4.96 \times 10^{4}$ cel. $L^{-1}$ (Station 2 Bottom - Dry season) to $47.75 \times 10^{4}{\mathrm{cel} . \mathrm{L}^{-1}}^{-}$ (Station 1 Subsurface - Rainy season).

Higher densities of Euglenophyta and Chlorophyta were observed in detriment to the Cyanophyta. Among the Euglenophyta, Trachelomonas volvocina was responsible for $82 \%$ and $24 \%$ of the total density of algal species in the rainy and dry seasons, respectively. In the rainy season, $T$. volvocina density varied according to depth, with higher density found at the subsurface. The highest densities of these algae coincided with higher rainfall periods (Fig. 2). Peridinium gatunense and Chlorella vulgaris presented high densities during the rainy season and Planktosphaeria gelatinosa presented high densities during the rainy season only at the subsurface of Station 2 . During the dry season, T. volvocina density was higher at the subsurface at both samplings stations (Fig. 2). 

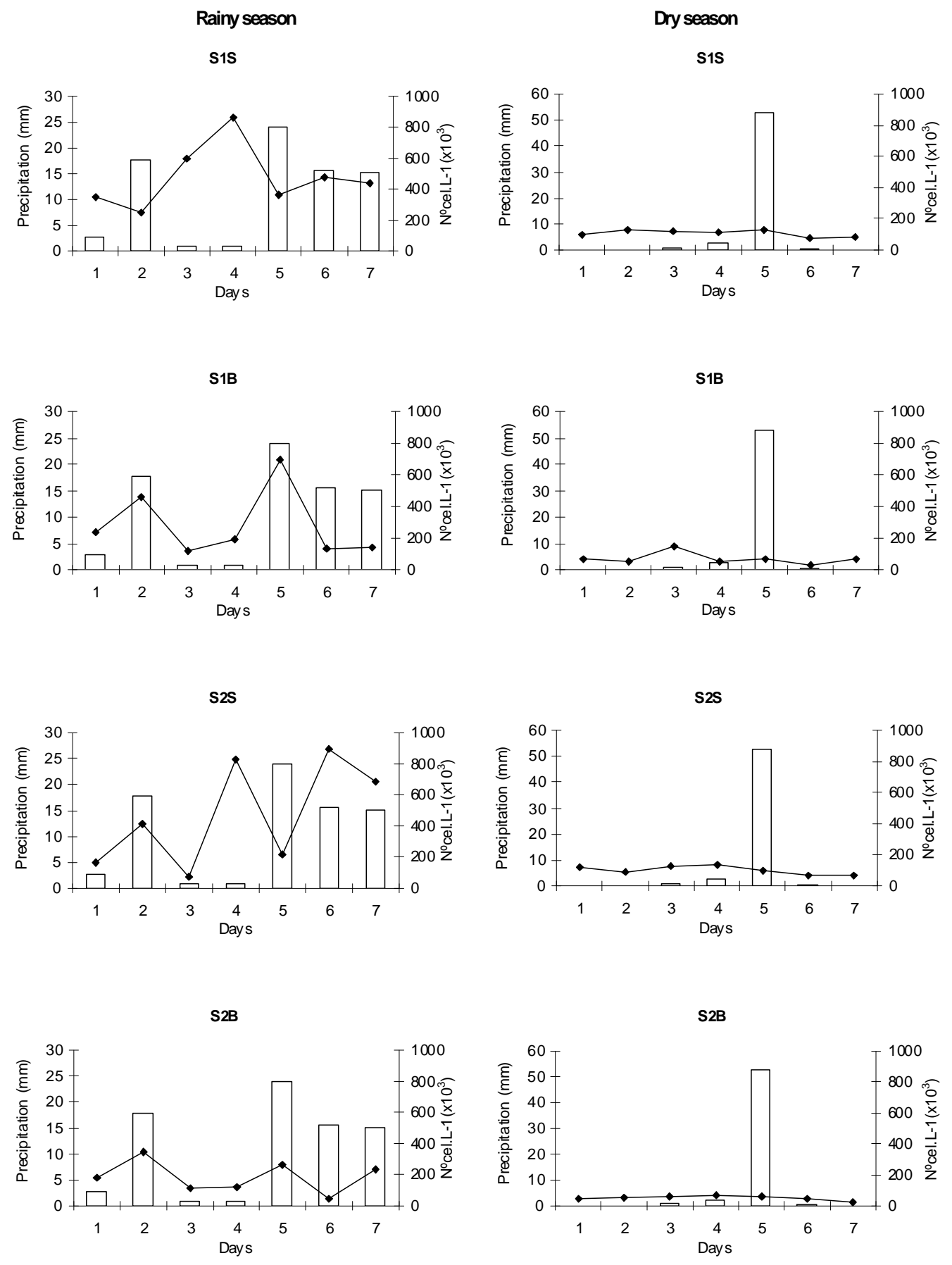

Figure 2 - Precipitation and total density of phytoplankton, in the sampling stations, at the rainy (and dry seasons, in the Botafogo reservoir-PE. (S1S): Station 1 Subsurface; (S1B): Station 1 Bottom; (S2S): Station 2 Subsurface; (S2B): Station 2 Bottom.

\section{Specific Diversity and Equitability}

Species diversity was consistently low at all sampling stations (Table 3) and during both the rainy and dry seasons, indicating that the phytoplankton community was formed by a relatively small number of species, among which one or two species exhibited high densities. During the rainy season, $T$. volvocina was the dominant species, whereas in the dry season, $P$. gelatinosa and $S$. planctonica were also encountered at high densities. 
Equitability was low in the rainy season, with values under 0.5 (exception for the bottom of Station 2, which was 0.62). Thus, the number of individuals was not well distributed among the different species. During the dry period, equitability values were above 0.5 , indicating a more even distribution of individuals among the different species (Table 3).

Table 3 - Specific diversity index and equitability values, in the sampling stations at the rainy and dry seasons, in the Botafogo Reservoir-PE. (S1S): Station 1 Subsurface; (S1B): Station 1 Bottom; (S2S): Station 2 Subsurface; (S2B): Station 2 Bottom.

\begin{tabular}{ccccccccc}
\hline Sampling Date & \multicolumn{4}{c}{ Specific Diversity $\left(\right.$ bits.cel. $\left.^{-1}\right)$} & \multicolumn{3}{c}{ Equitability } \\
\hline Rainy Season (Days) & S1S & S1B & S2S & S2B & S1S & S1B & S2S & S2B \\
\hline $07 / 07 / 03$ & 0.288 & 0.545 & 0.455 & 0.788 & 0.109 & 0.207 & 0.172 & 0.299 \\
$07 / 08 / 03$ & 0.436 & 0.341 & 0.417 & 0.506 & 0.165 & 0.129 & 0.158 & 0.192 \\
$07 / 09 / 03$ & 0.491 & 0.631 & 1.143 & 0.779 & 0.186 & 0.239 & 0.433 & 0.295 \\
$07 / 10 / 03$ & 0.426 & 0.826 & 0.763 & 0.837 & 0.161 & 0.313 & 0.289 & 0.317 \\
$07 / 11 / 03$ & 0.976 & 0.647 & 1.031 & 0.775 & 0.370 & 0.245 & 0.391 & 0.294 \\
$07 / 12 / 03$ & 0.581 & 0.832 & 0.594 & 1.631 & 0.220 & 0.315 & 0.225 & 0.618 \\
$07 / 13 / 03$ & 0.657 & 0.889 & 1.090 & 0.643 & 0.249 & 0.337 & 0.413 & 0.243 \\
\hline Dry Season & S1S & S1B & S2S & S2B & S1S & S1B & S2S & S2B \\
\hline $01 / 12 / 04$ & 1.637 & 1.673 & 1.611 & 1.597 & 0.522 & 0.534 & 0.514 & 0.509 \\
$01 / 13 / 04$ & 1.745 & 1.484 & 1.562 & 1.690 & 0.557 & 0.473 & 0.498 & 0.539 \\
$01 / 14 / 04$ & 1.709 & 1.001 & 1.688 & 1.253 & 0.545 & 0.319 & 0.538 & 0.400 \\
$01 / 15 / 04$ & 1.841 & 1.740 & 1.759 & 1.870 & 0.587 & 0.555 & 0.561 & 0.596 \\
$01 / 16 / 04$ & 1.661 & 1.696 & 1.724 & 1.794 & 0.530 & 0.541 & 0.550 & 0.572 \\
$01 / 17 / 04$ & 1.734 & 1.768 & 1.601 & 1.897 & 0.553 & 0.564 & 0.511 & 0.605 \\
$01 / 18 / 04$ & 1.964 & 1.979 & 1.852 & 1.797 & 0.626 & 0.631 & 0.591 & 0.573 \\
\hline
\end{tabular}

In the principal component analysis, the eigenvalues from the axes 1 and 2 explained $54.52 \%$ of data variability. Figure 3 displays the spatial projection of variables. Component 1 explained $43.01 \%$ of the data variance, demonstrating that the presence of $T$. volvocina, Chlorella vulgaris, Euglena sp. and P. gatunense was directly correlated with oxygen, turbidity, total nitrogen and was inversely correlated with water temperature, total dissolved solids, conductivity, transparency and $\mathrm{pH}$. Component 2 explained $11.51 \%$ of the variation, indicating that the presence of $P$. gelatinosa, $P$. gatunense and Euglena sp. was directly related to total nitrogen and inversely correlated with rainfall. Rainfall explained the occurrence of Monoraphidium arcuatum and C. vulgaris.

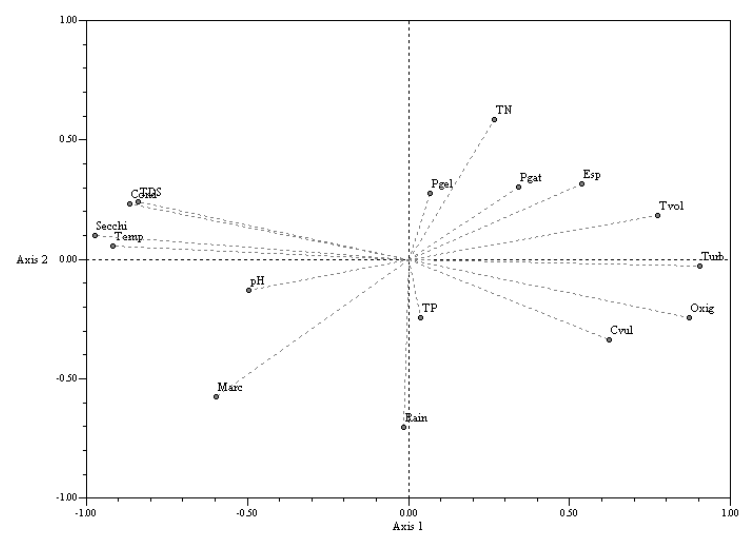

Figure 3 - Order of the principal components in Axes 1 and Axes 2. Tvol: T. volvocina, P.gat: Peridinium. gatunense, Pgel.: P. gelatinosa, Marc.: M. arcuatum, Cvul.: C. vulgaris, Esp.: Euglena sp., Cond.: Condutivity, Oxig.: Dissoved Oxygen, Temp.: Water Temperature, Turb.: Turbity, TDS: Total Dissolved Solids, Rain.: Rainy, TN: Total Nitrogen, TP: Total Phosphorus, Secchi: Secchi disk. 


\section{DISCUSSION}

In the Botafogo Reservoir, a significant presence of the Chlorophyta was determined during both the rainy and dry seasons, which was in agreement with results frequently reported for other reservoirs (Ramirez and Diaz 1994; Falcão et al., 2002 and Tucci and Sant'Anna, 2003). The predominance of Chlorophyta could be attributed to the alkaline $\mathrm{pH}$, as many Chlorococcales species seemed to prefer shallow waters with low transparency, such as in eutrophic lacustrine ecosystems that have been altered through anthropogenic activities (Sant'Anna and Martins, 1982). Although the Botafogo Reservoir did not reach alkaline $\mathrm{pH}$ values, the other environmental conditions cited by these authors were in fact encountered during the monitoring period, principally during the dry season when diversity was higher.

The high total density of algae observed during the rainy season (with a major contribution by $T$. volvocina) is related to the increased turbidity of the water during the period. Temporal variations in phytoplankton densities in tropical lakes are mainly controlled by the availability of nutrients and below-subsurface radiation (Esteves, 1998). These factors are, in turn, influenced by both external (wind, rain and incident radiation) and internal conditions (turbulence, stratification and mixing of the water column, as well as decomposition rates).

Characteristics observed in the Botafogo Reservoir seemed to indicate that the phytoplankton community was in an early successional stage. The association between the presence of $T$. volvocina and oxygen observed in the present study agreed with results found by John et al. (2002), who observed the presence of this species principally in ecosystems with low oxygen concentrations.

The positive correlation of $T$. volvocina and $C$. vulgaris with total nitrogen corroborated observations by Pômpeo (1996), who suggested that nitrogen was the main limiting factor to phytoplankton primary productivity in the reservoir of Lobo-SP. The relationship between turbidity and $T$. volvocina and $C$. vulgaris, as indicated by PCA, did not seem to be a limiting factor in the distribution of these species, as both was mobile: T. volvocina possesses flagella; and Wetzel (1993) observed that chlorophytes such as
C. vulgaris had drops of oil encrusted on their mucilaginous girdles, which gave them buoyancy. The higher microalgae diversity observed during the rainy season, mainly within the Chlorophyta division, was associated with low $\mathrm{pH}$ levels, with a consequent increase in dissolved $\mathrm{CO}_{2}$. It was also associated with the human activities near the reservoir. As the Botafogo reservoir is situated in an area with an intense sugar cane mono-culture, the hypertrophic state observed is certainly a direct reflection of these activities in the reservoir floodplain.

\section{ACKNOWLEDGMENTS}

The authors would like to thank the Brazilian Council for Research and Development - CNPq for the financial support of the program CTHIDRO - CNPq - Proc. 503850-2003-9 and ANM: 15111-2002-9 and 300612/2005-2.

\section{RESUMO}

O objetivo do presente estudo foi investigar a estrutura e dinâmica do fitoplâncton no reservatório de Botafogo-PE-Brasil. A comunidade fitoplanctônica foi identificada com literatura atualizada e a densidade estimada usando microscópio invertido. Concomitantemente as coletas das variáveis bióticas, foram medidos alguns parâmetros abióticos como temperatura da água, oxigênio dissolvido, condutividade e $\mathrm{pH}$ usando sondas de campo e transparência com disco de Secchi. Concentrações de fósforo total e nitrogênio total foram determinados em laboratório. Vinte e quatro táxons foram identificados tendo Chlorophyta apresentado maior número de espécie. A diversidade de espécie no reservatório foi baixa durante todo o período de estudo. A análise de componentes principais mostrou que Trachelomonas volvocina, Chlorella vulgaris, Euglena sp. e Peridinium gatunense esteve diretamente correlacionada com oxigênio dissolvido, turbidez e nitrogênio total. $P$. gelatinosa, Peridinim gatunense e Euglena sp. estiveram diretamente relacionada com nitrogênio total; a chuva explicou a ocorrência de Monoraphidium arcuatum e Chlorella vulgaris. 


\section{REFERENCES}

Ayres, M., Ayres Jr., M., Ayres, D. L. and Dos Santos, A. A. (2003), BioEstat, aplicações estatísticas nas áreas das ciências biomédicas. Belém-PA, Brasil.

Bouvy, M., Falcão, D., Marinho, M., Pagano, M. and Moura, A. (2000), Occurrence of Cylindrospermopsis (Cyanobacteria) in 39 brazilian tropical reservoirs during the 1998 drought. Aquatic Microbioogy Ecology, 23, 13-27.

Bouvy, M., Nascimento, S. M., Molica, R. J. R., Ferreira, A., Huszar, V. and Azevedo, S. M. F. O. (2003), Limnological features in Tapacurá reservoir (northeastern Brazil) during a severe drought. Hydrobiologia, 493, 115-130.

Bouvy, M., Pagano, M. and Troussellier, M. (2001), Effects of a cyanobacterial bloom (Cylindrospermopsis raciborskii) on bacteria and zooplankton communities in Ingazeira reservoir (northeast Brazil). Aquatic Microbioogy Ecolology, 25, 215-227.

Calijuri, C. M. and Dos Santos, A. C. A. (2001), Temporal variations in phytoplankton primary production in a tropical reservoir (Barra Bonita, SP, Brazil). Hydrobiologia, 445,11-26.

Calijuri, M. C., Dos Santos, A. C. A. and Jati, S. (2002), Temporal changes in the phytoplankton community structure in a tropical and eutrophic reservoir (Barra Bonita, SP-Brazil). Journal Plankton Research, 24, 617-634.

Chellapa. N. T. (1990), Phytoplankton species composition, chlorophyll biomass and primary production of the Jundiaí Reservoir (northeastern Brazil) before and after eutrophization. Acta Hydrobiologica, 32, 75-91.

Chellapa, W. T., Costa, J. A. S. and Araújo, M. F. F. (1998), Estudo do fitoplâncton da Barragem Eng. Armando Ribeiro Gonçalves, Assú, Rio Grande do Norte. Acta Limnologica Brasiliensia, 10 (1), 68-77.

Costa, I. A. S., Azevedo, S.M.F.O., Senna, P. A.C., Bernardo, R.R., Costa, S. M. and Chellappa, N.T. (2006), Occurrence of toxin-producing cyanobacteria blooms in a Brazilian Semiarid reservoir. Braz. J. Biol., 66 (1B), 211-219.

De Bernardi, R. (1984), Methods for the estimation of Zooplankton abundance. In - Downing and Rigler, $A$ manual on Methods for the Assessment of Secondary Productivity in Freshwaters. 2. ed. Oxford, Blackwell Sci. Publ. (I. B. P. Hand, 17). 59-63.

Esteves, F. A., (1998), Fundamentos da Limnologia. Rio de Janeiro, Interciência/FINEP, Rio de Janeiro. pp. 602 .
Falcão, D., Moura, A. N., Pires, A. H. B., Bouvy, M., Marinho, M., Ferraz, A. C. N. and Silva, A. M. (2002), Diversidade de microalgas planctônicas de mananciais localizados nas zonas fitogeográficas: Mata, Agreste e Sertão do Estado de Pernambuco. In Tabarelli, M. and Silva, J. M. C. Diagnóstico da Biodiversidade de Pernambuco, Recife: Secretaria de Ciência, Tecnologia e Meio Ambiente. pp. 79-91.

Figueredo, C. C.and Giani, A. (2001), Seasonal variation in the diversity and species richness of phytoplankton in a tropical eutrophic reservoir. Hydrobiologia, 445, 165-174.

Henry, R., Nogueira, M. G., Pômpeo, M. L. M. and Moschini-Carlos, V. (2006), Annual and short-term variability in primary productivity by phytoplankton and correlated abiotic factors in the Jurumirim reservoir (São Paulo, Brazil). Braz. J. Biol., 66 (1B), 239-261.

John, M., Whitton, B. A. and Brook, A. J. (2002), The freshwater algal flora of the British Isles: an identification guide to freshwater and terrestrial algae. The Natural History Museum and the British Phycological Society. Cambridge University. pp. 703.

Komárek, J. and Foot. B. (1983), Das Phytoplankton des Süsswasser Systematik und Biologie. 7. Teil: Chlorophyceae (Grünalgen) Ordnung: Chlorococcales. In: Elster. H.-J. and Ohle, W. (Eds): Die Binnengewässer. Begründet von August Thienemann, Stutgart.

Komárek, J. and Anagnostidis, K. (1999), Cyanoprokaryota. 1. Teil: Chroococcales. In: Ettl, H., Gärtner, G. and Heynig, H. and Mollenhauer, D. (eds): Süsswasser von Mitteleuropa. Gustav Fischer, Stutgart.

Komárek, J. and Anagnostidis, K. (2005), Cyanoprokaryota 2. Teil: Oscillatoriales. Süsswasser von Mitteleuropa. B. Bridel G. Gastner, L. Krienitz and M. Schargerl (Hrs.) 19/2. Elsevier. 759p.

Marinho, M. M. and Huszar, V. L. M. (2002), Nutrient availability and physical conditions as controlling factors of phytoplankton composition and biomass in a tropical reservoir (Southeastern Brazil). Archive fur Hydrobiologie, 153, 443-468.

NTSYS-PC. (2000), Numerical taxonomy and multivariate analyses system - NTSYS-PC 2.1, Metagraphics software corporation, California-USA.

Pompêo, M. L. M. (1996), Produtividade primária do fitoplâncton e tipologia da Lagoa Dourada (Brotas, SP). In: Anais VII Seminário Regional de Ecologia. São Paulo. São Paulo. 7, 15-25.

Ramírez, R. J. J. and Díaz, C. A. (1994), Caracterización limnológica y estrutura de la comunidad fitoplanctónica en la Laguna Del Parque Norte, Medellín, Colombia. Hoehnea, 21, 7-28. 
Round, F. E.; Crawford, R. M. and Mann, D. G (1990), The Diatoms. Biological and morphology of the genera. Cambridge. pp. 747

Sant'Anna, C. L. (1984), Chlorococcales (Chlorophyceae) do Estado de São Paulo, Brasil. São Paulo, p. 348.

Sant'Anna, C. L. and Martins, D. V. (1982), Chlorococcales (Chlorophyceae) dos Lagos Cristalino e São Sebastião, Amazonas, Brasil: taxonomia e aspectos limnológicos. Revista Brasileira de Botânica, 5, 67-82.

Sant'Anna, C. L., Sormus, L., Tucci, A., Azevedo, M. T. P. (1997), Variação sazonal do fitoplâncton do Lago das Garças, São Paulo, SP. Hoehnea, 24, 67-86.

Shannon, C. E. and Weaver, W. The mathematical theory of communication, Urbana, Illinois University Press. 177p. 1963.

Straskraba, M. and Tundisi, J. G., (2000), Diretrizes para o gerenciamento de lagos: gerenciamento da qualidade dos lagos. São Carlos - São Paulo. pp. 280.

Thornton, K. E., Kimmel, B. L. and Payne, F. E. (1990), Reservoir Limnology: Ecological perpectives. John Wiley and Sons. New York. pp. 246.

Tucci, A. and Sant'Anna, C. L. (2003), Cylindrospermopsis raciborskii (Woloszynska)
Seenayya and Subba Raju (Cyanobacteria): variação semanal e relações com fatores ambientais em um reservatório eutrófico, São Paulo, Brasil. Revista Brasileira de Botânica, 26, 97-112.

Tundisi, J. G. (1999), Reservatórios como sistemas complexos: Teoria, aplicações e perspectivas para usos múltiplos. In: Henry, R. (Ed). Ecologia de reservatórios: Estrutura, Função e Aspectos Sociais. Fapesp/Fundibio, São Paulo, pp.19-38.

Utermöhl, H. (1958), Zur Vervollkomnung der quantitativen Phytoplankton-Methodik. Mitt. int. Ver. Limnol., 9, 1- 38.

Valderrama, G. C. (1981), The simultaneous analysis of total nitrogen and total phosphorus in natural waters. Marine Chemistry, 10, 109-122.

Wetzel, R. G. (1993), Limnologia. Porto Alegre: Fundação Calouste Gulbenkian, Porto Alegre pp. 91.

Received: May 05, 2006; Revised: June 13, 2007; Accepted: July 02, 2008. 